Vol. 59: e16150484, January-December 2016 http://dx.doi.org/10.1590/1678-4324-2016150484

ISSN 1678-4324 Online Edition
BRAZILIAN ARCHIVES OF BIOLOGY AND TECHNOLOGY

AN INTERNATIONAL JOURNAL

\title{
Comparative study of a new alkaline L-methioninase production by Aspergillus ustus AUMC 10151 in submerged and solid-state fermentation
}

\author{
Medhat Ahmed Abu-Tahon ${ }^{1}$; George Saad Isaac ${ }^{1 *}$ \\ ${ }^{1}$ Faculty of Education, Ain Shams University, Biological and Geological Sciences Department, Cairo, Egypt
}

\begin{abstract}
Twenty four fungal species were screened for their ability to produce alkaline L-methioninase on methionineglucose liquid medium. Aspergillus ustus AUMC 10151 displayed the highest yield of enzyme (10.8 U/mg protein), followed by A. ochraceus and Fusarium proliferatum. Upon optimization of the submerged fermentation $(\mathrm{SmF})$ conditions, the maximum enzyme yield $(18.23 \mathrm{U} / \mathrm{mg}$ protein) was obtained on a medium containing L-methionine (0.5\%), sucrose (0.95\%), $\mathrm{KH}_{2} \mathrm{PO}_{4}(0.1 \%)$ and $175 \mathrm{rpm}$. Seven agro-industrial byproducts were screened as substrates for L-methioninase production under solid-state fermentation (SSF). Wheat bran resulted $38.1 \mathrm{U} / \mathrm{mg}$ protein, followed by rice bran (27.6 U/mg protein) and soya bean meal (26.6 U/mg protein). Maximum alkaline L-methioninase (99.56U/mg protein) was achieved at initial moisture content

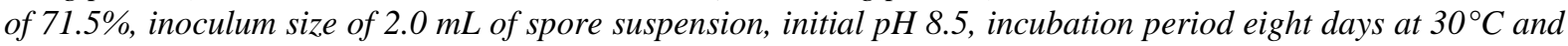
supplementation of the salt basal medium with pyridoxine $(100 \mu \mathrm{g} / \mathrm{mL})$ and beet molasses $(20 \% \mathrm{v} / \mathrm{v})$. The productivity of L-methioninase by A. ustus under SSF was higher than that of SmF about 5.45 fold under optimum conditions.
\end{abstract}

Key words: L-methioninase, Aspergillus ustus, Submerged fermentation, Solid state fermentation, Wheat bran.

\footnotetext{
${ }^{1}$ Author for correspondence: dr.georgesaad@ gmail.com
} 


\section{INTROCUCTION}

L-methioninase (E.C.4.4.1.11) is a pyridoxal L-phosphate dependent enzyme that catalyzes the deamination and demethiolation of Lmethionine to $\alpha$-ketobutyrate, methanethiol and ammonia (Ruiz-Herrera and Starkey 1969a). Microbial L-metioninase has received much attention since it shows anti-proliferative activity towards various types of malignant cells (Cellarier et al. 2003). The antitumor activity of L-methioninase elaborates from the absence of tumor cells to methionine-synthase (Halpern et al. 1974). Consequently, these cells are auxotrophic for L-methionine, depending absolutely on the exogenous supply of L-methionine for their survival and proliferation (Kokkinakis et al. 1997), whereas normal cells are relatively resistant to exogenous L-methionine restriction because it contains active methionine synthase (Bergstorm et al. 1987).

Therapeutic efficiency of bacterial Lmethioninase has rarely occurred without some evidence of toxicity and immunogenic reactions, especially with regard to multiple doses (Tan et al. 1997). Therapeutic efficiency of fungal L-methioninase occurs with fewer immunogenic and allergic reactions, which may be attributed to the higher specificity of their substrates compared with the substrate analogues, displaying less problems during the course of tumor therapy (Hawkins et al. 2004). L-methioninase production by fungi under submerged fermentation (SmF) by Aspergillus sp. (Ruiz-Herrera and Starkey 1969b), Debaromycs hanseni (Bonnarme et al. 2001), A. flavipes (Khalaf and El-Sayed 2009) has been reported. SSF has also been reported for its production by A. flavus (El-Sayed 2009). Physiologically L-methionine can be rapidly oxidized through Millard reactions forming amadori compounds that consequently reduce their bioavailability as carbon and nitrogen for the organism (Delgado-Andrade et al. 2007). Thus, using L-methionine as substrate for enzyme induction could be, at least technically, not the superior substrate, in addition to the economic expense of these medium components (El-Sayed 2010). Consequently, the search for a novel producers and new forms of the growth medium for large scale production for this enzyme will be a challenge. SSF on agro-industrial residues promises a cost-effective bioprocess as it requires small vessels and gives a higher yield (El-Sayed 2009). SSF for the enzyme production employing methionine-containing solid substrates displayed a more stable physical form of bounded methionine that could be a new strategy from the technical and economical points of views (El-Sayed 2009).

Practically no comprehensive studies on the potential of filamentous fungi for the Lmethioninase production (Khalaf and El-Sayed 2009). Therefore, in this study, the potential of A. ustus AUMC 10151 for production of alkaline L-methioninase was optimized under $\mathrm{SmF}$ and SSF. To our knowledge, this is the first paper on the production of extracellular alkaline L-methioninase from A. ustus under SmF and SSF conditions.

\section{MATERIAL AND METHODS}

\section{Microorganism}

Fungi used in this work were previously isolated from Mangrove soil of Ras Mohammed protected area at Sharm ElSheikh, Egypt and different soil samples from Kingdom Saudi Arabia and identified by Assiut University Mycological Centre (AUMC), Egypt. All the cultures were deposited in AUMC with their accession numbers. These fungi were grown on Czapek's agar medium at $30^{\circ} \mathrm{C}$ for seven days and subcultured whenever required.

\section{Material}

Nessler's reagent, Folin reagent, pyridoxine, soya bean meal and corn steep liquor were obtained from Sigma-Aldrich (St. Louis, Mo). Cane and beet molasses were obtained from Hawamdiah and Kafr El-Sheikh sugar factories, respectively. Crude whey was collected from the rural area of Kalyoubia governorate, Egypt and agro-industrial byproducts, such as wheat bran, wheat straw, rice bran, rice husk, sugar cane bagasse, and corn cobs were obtained locally. All other chemicals were of analytical grade.

\section{Treatment of Beet and Cane molasses}

Two hundred milliliter of either cane, or beet molasses was diluted to one liter by tap water, autoclaved, and then filtered to remove the precipitated mud. The filtrate was stored in dark bottles in refrigerator until use. Molasses and whey were analyzed for nitrogen content, carbohydrates and minerals by the Services 
Central Lab, National Research Centre CairoEgypt.

\section{Screening of fungal methioninolytic potentialities under $\mathrm{SmF}$}

The fungal isolates were screened for their Lmethioninase productivity using modified methionine-glucose liquid medium as described by Ruiz-Herrera and Starkery (1969a). Triplicate sets of $250 \mathrm{~mL}$ Erlenmeyer flasks containing $50 \mathrm{~mL}$ of sterilized medium containing $(\mathrm{g} / \mathrm{L})$ : methionine 5.0; glucose 10; $\mathrm{KH}_{2} \mathrm{PO}_{4} 1.0 ; \mathrm{MgCl}_{2} \cdot 6 \mathrm{H}_{2} \mathrm{O} 0.5 ; \mathrm{CaCl}_{2} \cdot 2 \mathrm{H}_{2} \mathrm{O}$ $0.1 ; \mathrm{FeCl}_{3} \cdot 6 \mathrm{H}_{2} \mathrm{O} 0.02$ and $\mathrm{ZnCl}_{2} 0.02$ were used. The medium was adjusted to $\mathrm{pH} 8.0$ using $0.1 \mathrm{~N} \mathrm{NaOH}$, inoculated with $1.0 \mathrm{~mL}$ of fresh spore suspension obtained from 7-days old cultures of the fungi and incubated at $30^{\circ} \mathrm{C}$ for six days in at $1.7 \mathrm{x} \mathrm{g}$. The cultures were then filtered through Whatman No. 1 filter paper and the supernatant was centrifuged at $4000 \mathrm{rpm}$ for $5 \mathrm{~min}$, then the enzyme activity and total protein were measured as described below.

\section{Solid-State Fermentation (SSF)}

Wheat bran, wheat straw, rice bran, rice husk, sugar cane bagasse, soya bean meal and corn cobs were screened for alkaline Lmethioninase production under SSF by A. ustus. Five gram of each dried substrate in 250 $\mathrm{mL}$ Erlenmeyer conical flasks was moistened with $5.0 \mathrm{~mL}$ of the optimized $\mathrm{SmF}$ medium without methionine. After autoclaving, the medium was inoculated with $1 \mathrm{~mL}$ of fungal spore suspension of 7-days old culture of $A$. ustus and incubated at $30^{\circ} \mathrm{C}$ for eight days. The fermented substrate was thoroughly mixed with $50 \mathrm{~mL}$ of $0.2 \mathrm{M}$ Glycine-NaOH buffer $(\mathrm{pH} 8.0)$ using a rotary shaker at $3 \mathrm{x}$ g for 30 min. The whole content of each flask was filtered through muslin cloth and the pooled filtrate was centrifuged at $1252 \mathrm{x} \mathrm{g}$ at $4^{\circ} \mathrm{C}$ for $15 \mathrm{~min}$. The clear supernatant was used as the crude enzyme preparation.

\section{Optimization of alkaline L-methioninase production parameters}

The L-methioninase production parameters were optimized under $\mathrm{SmF}$ and SSF conditions. In SmF, the L-methionine-free medium was supplemented with various nitrogen sources, namely, L-asparagine, Lglutamine, glysine, tyrosine, urea, beef extract, yeast extract, ammonium chloride, ammonium sulphate and sodium nitrate. The added nitrogen sources were in equimolecular weight to nitrogen base of methionine in fermentation medium. Several carbon sources, namely, arabinose, mannitol, sorbitol, sucrose, lactose, maltose, cellulose and starch were supplemented to the fermentation medium in equimolecular weight to carbon in glucose. The effect of shaking velocity $(100,125,150$, 175 and $200 \mathrm{rpm}$ ) was investigated. In addition, the SSF was also optimized through various parameters including moisture content of substrate $(58,71.5,78.3,82$ and $85 \%)$, size of inoculum $(0.5,1.0,1.5,2.0,2.5,3.0,3.5$ and $4.0 \mathrm{~mL}$ of spores suspension), initial $\mathrm{pH}$ of basal medium $(7.0,7.5,8.0,8.5,9.0,9.5,10.0$, 10.5 and 11.0). The effect of supplementation of the basal medium with some vitamins as ascorbic acid, biotin, folic acid, pantothenic acid, pyridoxine, and riboflavin $(100 \mu \mathrm{g} / \mathrm{mL})$ and different by-products (whey, cane molasses, beet molasses and corn steep liquor) as additives $(20 \%, \mathrm{v} / \mathrm{v})$ was also ascertained.

\section{L-methioninase assay}

The activity of alkaline L-methioninase was determined using Nessler's reagent (Thompson and Morrison 1951) with some modification as follow: $1.0 \mathrm{~mL}$ of the enzyme preparation was incubated with $1.0 \mathrm{~mL}$ of $1 \%$ L-methionine in $0.2 \mathrm{M}$ Glycine- $\mathrm{NaOH}$ buffer ( $\mathrm{pH} 8.0$ ) and 0.1 $\mathrm{mL}$ of pyridoxal phosphate at $30^{\circ} \mathrm{C}$ for $1 \mathrm{~h}$. The crude enzyme was extracted from the solid fermented substrate by a simple contact method with minor modification (Horvath 1972). The enzyme activity was stopped by adding $0.5 \mathrm{~mL}$ of $1.5 \mathrm{~N}$ trichloroacetic acid, followed by centrifugation at $1957 \mathrm{xg}$ for 5 min. The released ammonia was determined using $0.5 \mathrm{~mL}$ Nessler's reagent; the developed color was measured at $480 \mathrm{~nm}$. Enzyme and substrate blanks were used. One unit of Lmethioninase was defined as the amount of enzyme that liberated one $\mu$ mole of ammonia/h under optimal assay conditions. Specific activity of L-methioninase was expressed as the activity of enzyme in term of units per milligram of protein.

\section{Protein Determination}

Protein was determined by Lowry et al. (1951) method using bovine serum albumin as the standard. 


\section{Statistical Analysis}

The data were statistically analyzed with SPSS (Scientific Package for Scientific Social Studies, version 20), in which the equations of the hypothesis tests, including the mean, standard deviation, T-statistics value and probabilities (p) were used. Results were considered highly significant, significant, or non-significant, where $\mathrm{p} \leq 0.01, \mathrm{p} \leq 0.05$ and $\mathrm{p}$ $>0.05$, and represented by $* * *, * *$ and $*$, respectively. The data were statistically compared to the highest value obtained, which was marked as $\bullet$.

\section{RESULTS}

Screening for fungi producing alkaline Lmethioninase under SmF

Potentialities of twenty-four fungal species were investigated for their ability to produce alkaline L-methioninase on methionineglucose liquid medium ( $\mathrm{pH}$ 8.0). These species belonged to nine genera, namely, Aspergillus, Cunninghamella, Emericella, Fusarium, Humicola, Paecilomyces, Penicillium, Rhizopus and Trichoderma. The results in Table 1 showed that the maximum alkaline Lmethioninase productivity (10.8 U/mg protein) was obtained by $A$. ustus, followed by $A$. ochraceus, Fusarium proliferatum, Penicillium crustosun and Trichoderma longibrachiatum, which produced 9.1, 8.9, 8.5 and $8.0 \mathrm{U} / \mathrm{mg}$ protein, respectively. The lowest enzyme productivity was obtained by Paecilomyces lilacinus (5.8 U/mg protein), followed by $P$. citrinum, $H$. grisea, and $P$. corylophilum, they produced 6.1, 6.3 and 6.8 $\mathrm{U} / \mathrm{mg}$ protein, respectively.

Table 1- Screening for alkaline L-methioninase production by investigated fungi

\begin{tabular}{|c|c|c|c|c|c|c|}
\hline & Fugal species & $\begin{array}{l}\text { AUMC } \\
\text { No. }\end{array}$ & $\begin{array}{l}\text { L- } \\
\text { methioninase } \\
\text { activity } \\
(\mathrm{U} / \mathrm{mL})\end{array}$ & $\begin{array}{l}\text { Protein } \\
\text { content } \\
(\mathrm{mg} / \mathrm{mL})\end{array}$ & $\begin{array}{l}\text { Specific } \\
\text { activity } \\
\text { (U/mg) }\end{array}$ & $\begin{array}{l}\text { Biomass } \\
(\mathrm{g} / \mathrm{L})\end{array}$ \\
\hline \multirow{15}{*}{ 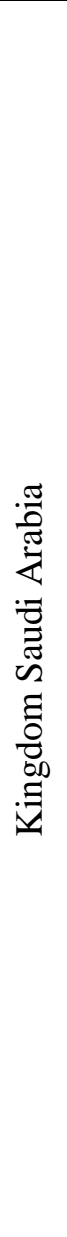 } & Aspergillus flavus Link & 8653 & 115 & 16 & $\begin{array}{l}7.2 \\
\pm 0.77^{* * *}\end{array}$ & $2.46 \pm 0.09$ \\
\hline & A. fumigatus Fresenius & 8594 & 163 & 22 & $7.4 \pm 1.2^{* * *}$ & $3.10 \pm 0.05$ \\
\hline & A. niger Van Tieghem & 8593 & 210 & 29 & $\begin{array}{l}7.2 \\
\pm 0.45^{* * *}\end{array}$ & $4.60 \pm 0.17$ \\
\hline & A. ochraceus Wilhelm & 8670 & 210 & 23 & $9.1 \pm 0.55^{* *}$ & $4.12 \pm 0.10$ \\
\hline & $\begin{array}{l}\text { A. sydowii (Bainier and Sartory) } \\
\text { Thom and Church }\end{array}$ & 8660 & 160 & 22.8 & $\begin{array}{l}7.0 \\
\pm 0.99^{* * * *}\end{array}$ & $4.56 \pm 0.12$ \\
\hline & A. terreus Thom & 8605 & 170 & 22.7 & $\begin{array}{l}7.5 \\
\pm 0.76^{* * *}\end{array}$ & $5.12 \pm 0.08$ \\
\hline & $\begin{array}{l}\text { Cunninghamella phaeospora } \\
\text { Boedijn }\end{array}$ & 8662 & 130 & 19.12 & $6.79 \pm 1.03$ & $2.89 \pm 0.06$ \\
\hline & $\begin{array}{l}\text { Emericella nidulans } \\
\text { (Eidam)Vuillemin }\end{array}$ & 8640 & - & - & - & - \\
\hline & $\begin{array}{l}\text { E. quadrilineata (Thom and } \\
\text { Raper) Benjamin }\end{array}$ & 8636 & - & - & - & - \\
\hline & $\begin{array}{l}\text { Fusarium proliferatum } \\
\text { (Matsush.)Nirenberg }\end{array}$ & 8617 & 210 & 23.5 & $8.9 \pm 1.00^{* *}$ & $4.87 \pm 0.15$ \\
\hline & F. solani (Martius) Saccardo & 8615 & 166 & 22.8 & $\begin{array}{l}7.28 \\
\pm 1.06^{* * *}\end{array}$ & $3.92 \pm 0.11$ \\
\hline & Humicola grisea Traaen & 8598 & 120 & 19 & $\begin{array}{l}6.3 \\
\pm 1.04^{* * *}\end{array}$ & $2.12 \pm 0.06$ \\
\hline & $\begin{array}{l}\text { H. insolens Cooney and } \\
\text { Emerson }\end{array}$ & 8607 & - & - & - & - \\
\hline & Penicillium chrysogenum Thom & 8656 & 200 & 26 & $\begin{array}{l}7.7 \\
\pm 0.76^{* * *}\end{array}$ & $5.23 \pm 0.08$ \\
\hline & P. corylophilum Diercks & 8601 & 170 & 25.1 & 6.8 & $4.83 \pm 0.13$ \\
\hline
\end{tabular}




\begin{tabular}{|c|c|c|c|c|c|c|}
\hline & & & & \multicolumn{3}{|c|}{ $\pm 0.43^{* * *}$} \\
\hline & P. duclauxii Delacroix & 8667 & 198 & 26.9 & $\begin{array}{l}7.4 \\
\pm 0.34^{* * *}\end{array}$ & $3.60 \pm 0.11$ \\
\hline & $\begin{array}{l}\text { Rhizopus stolonifera } \\
\text { (Ehrenberg) Vuillemin }\end{array}$ & 8671 & 215 & 27.45 & $\begin{array}{l}7.8 \\
\pm 0.68^{* * *}\end{array}$ & $2.98 \pm 0.09$ \\
\hline & A. flavus Link & 10150 & 109 & 14.8 & $\begin{array}{l}7.4 \\
\pm 0.94^{* * *}\end{array}$ & $2.23 \pm 0.15$ \\
\hline \multirow{6}{*}{ 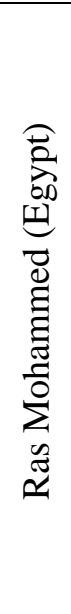 } & A. niger Van Tieghem & 10146 & 120 & 16.9 & $\begin{array}{l}7.1 \\
\pm 0.33^{* * *}\end{array}$ & $3.23 \pm 0.11$ \\
\hline & $\begin{array}{l}\text { A. ustus (Brinier) Thom and } \\
\text { Church }\end{array}$ & 10151 & 245.5 & 22.8 & $\begin{array}{l}10.8 \pm 0.20 \\
\bullet\end{array}$ & $5.40 \pm 0.22$ \\
\hline & P. citrinum Thom & 10147 & 169 & 27.6 & $\begin{array}{l}6.1 \\
\pm 0.88^{* * *}\end{array}$ & $4.33 \pm 0.21$ \\
\hline & P. crustosun Thom & 10148 & 187 & 22 & $\begin{array}{l}8.5 \\
\pm 0.13^{* * *}\end{array}$ & $3.56 \pm 0.26$ \\
\hline & $\begin{array}{l}\text { Paecilomyces lilacinus (Thom) } \\
\text { Samson }\end{array}$ & 10149 & 160 & 27.8 & $\begin{array}{l}5.8 \\
\pm 0.16^{* * *}\end{array}$ & $3.54 \pm 0.07$ \\
\hline & $\begin{array}{l}\text { Trichoderma longibrachiatum } \\
\text { Rifai }\end{array}$ & 10155 & 220 & 27.45 & $\begin{array}{l}8.0 \\
\pm 0.11^{* * *}\end{array}$ & $5.45 \pm 0.04$ \\
\hline
\end{tabular}

AUMC $=$ Assiut University Mycological centre; Data represent the mean of three different readings approximated to two decimal \pm standard deviation. ${ }^{* * *}$ Highly significant, $\mathrm{p} \leq 0.01$. Data was statistically compared using t-test $(\mathrm{N}=3)$.

The obtained data were statistically compared to the highest value obtained, which is marked as $\bullet$.

Effect of nitrogen sources on alkaline Lmethioninase production by $A$. ustus

A set of synthetic or natural nitrogen sources was separately added as a sole nitrogen source to the fermentation medium in equimolecular weight to nitrogen base of methionine $(0.5 \%)$. As shown in Figure 1, maximum Lmethioninase produced $10.74 \pm 0.82 \mathrm{U} / \mathrm{mg}$ protein by $A$. ustus with the addition of $\mathrm{L}$ methionine. Other nitrogenous sources showed an inhibitory effect on production of alkaline L-methioninase. The results showed that the maximum growth rate was recorded with $\mathrm{L}$ glutamine $(7.0 \pm 0.04 \mathrm{~g} / \mathrm{L})$, followed by yeast extract $(6.50 \pm 0.09 \mathrm{~g} / \mathrm{L})$ as nitrogen source.

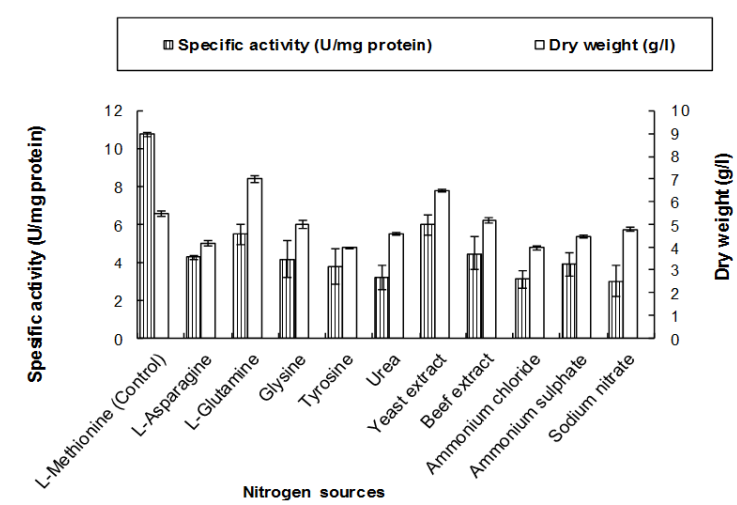

Figure 1- Effect of different nitrogen sources on alkaline L-methioninase production by $A$. ustus under Submerged Fermentation.
Effect of carbon sources on alkaline Lmethioninase production by A. ustus

Figure 2 showed that the maximum alkaline Lmethioninase production and growth yield by A.ustus were recorded with sucrose (12.82 \pm $0.18 \mathrm{U} / \mathrm{mg}$ protein and $5.8 \pm 0.09 \mathrm{~g} / \mathrm{L}$, respectively), followed by mannitol (12.0 \pm $0.11 \mathrm{U} / \mathrm{mg}$ protein and $5.3 \pm 0.06 \mathrm{~g} / \mathrm{L}$, respectively). Without any carbon source, the specific activity of L-methioninase and growth rate showed lowest value $(2.6 \pm 0.35 \mathrm{U} / \mathrm{mg}$ protein and $2.43 \pm 0.10 \mathrm{~g} / \mathrm{L}$, respectively).

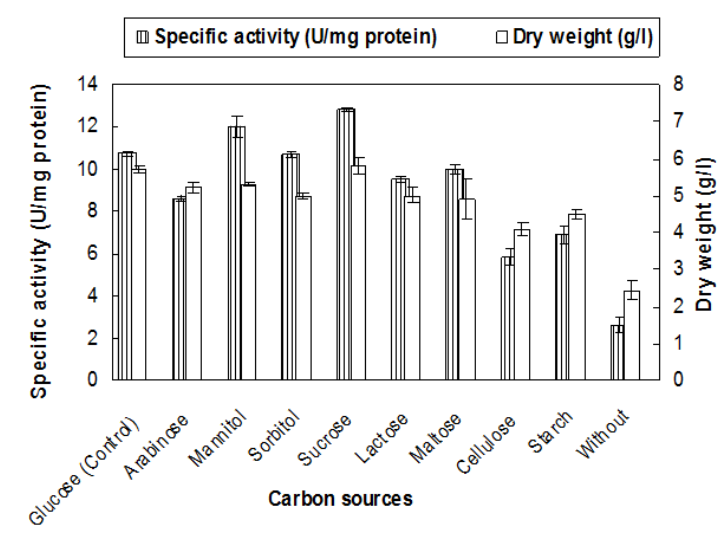

Figure 2- Effect of different carbon sources on alkaline L-methioninase production by $A$. ustus under $\mathrm{SmF}$. 
Effect of shaking velocity on the production of alkaline L-methioninase by $A$. ustus

Figure 3 showed that $175 \mathrm{rpm}$ was the optimum shaking velocity for the maximum accumulation of alkaline L-methioninase and growth yield by $A$. ustus $(18.23 \pm 1.1 \mathrm{U} / \mathrm{mg}$ protein and $6.3 \pm 0.1 \mathrm{~g} / \mathrm{L})$.

Screening for alkaline L-methioninase production by $A$. ustus using different agroindustrial by-products under SSF

Table 2 showed that the maximum yield of alkaline L-methioninase by A. ustus was by wheat bran $(38.1 \pm 0.99 \mathrm{U} / \mathrm{mg}$ protein), followed by rice bran $(27.6 \pm 1.31 \mathrm{U} / \mathrm{mg}$ protein), soya bean meal $(26.6 \pm 0.55 \mathrm{U} / \mathrm{mg}$ protein), corn cobs $(23.0 \pm 1.52 \mathrm{U} / \mathrm{mg})$ and sugar cane bagasse $(22.6 \pm 0.67 \mathrm{U} / \mathrm{mg}$ protein).

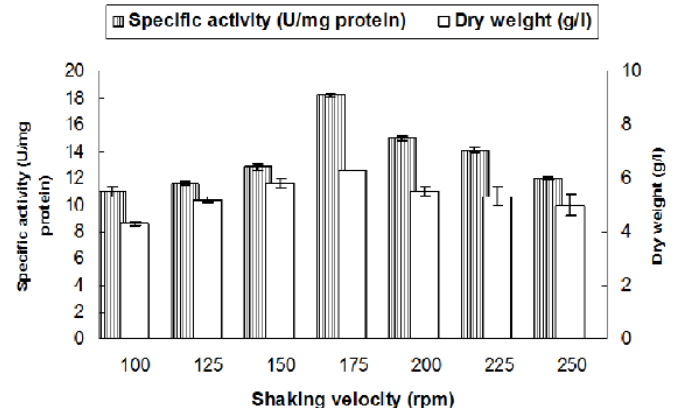

Figure 3- Effect of shaking velocity on alkaline L-methioninase production by $A$. ustus under SmF.

Table 2- Screening for alkaline L-methioninase production by A. ustus using different agro-industrial byproducts

Data represent the mean of three different readings approximated to two decimal \pm standard deviation.

\begin{tabular}{lccc}
\hline Substrate & $\begin{array}{c}\text { L-methioninase activity } \\
(\mathrm{U} / \mathrm{ml})\end{array}$ & $\begin{array}{c}\text { protein } \\
(\mathrm{mg} / \mathrm{ml})\end{array}$ & $\begin{array}{c}\text { L-methioninase Specific } \\
\text { activity }(\mathrm{U} / \mathrm{mg} \text { protein })\end{array}$ \\
\hline Wheat bran & 15.22 & 0.40 & $38.1 \pm 0.99$ \\
Wheat straw & 11.2 & 0.66 & $17.0 \pm 0.53$ \\
Rice bran & 15.2 & 0.55 & $27.6 \pm 1.31$ \\
Rice husk & 12.5 & 0.68 & $18.4 \pm 0.87$ \\
Sugar cane bagasse & 12 & 0.53 & $22.6 \pm 0.67$ \\
Soya bean meal & 16.2 & 0.61 & $26.6 \pm 0.55$ \\
Corn cobs & 12.2 & 0.53 & $23.0 \pm 1.52$ \\
\hline
\end{tabular}

\section{Effect of initial moisture content on alkaline L-methioninase production by $\mathrm{A}$. ustus under SSF}

Figure 4 demonstrated the effect of different ratios of salt basal medium at fixed weight of wheat bran $(0.5 \mathrm{~g})$. The maximal production of alkaline L-methioninase was obtained at the ratio of 1:2 (44.8 $\pm 1.38 \mathrm{U} / \mathrm{mg}$ protein) with initial moisture content of $71.5 \%$. An increase in the moisture content of the substrate than $78.3 \%$ resulted in a great decline in alkaline Lmethioninase yield.

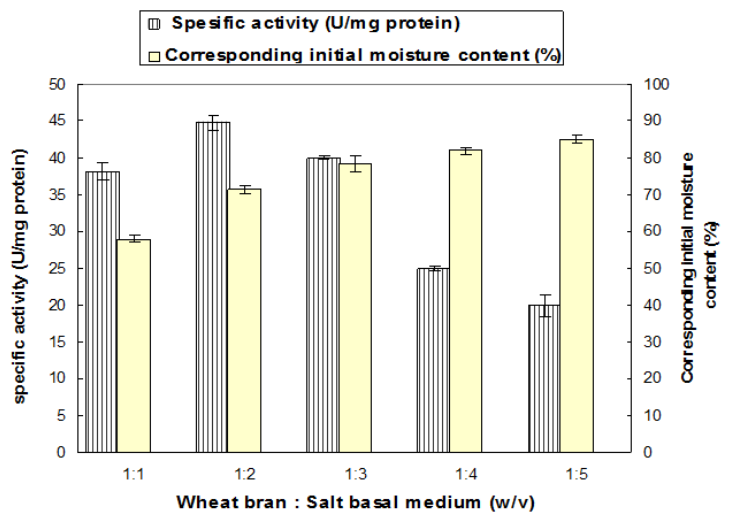

Figure 4- Effect of initial moisture content on alkaline L-methioninase production by $A$. ustus under Solid State Fermentation

Effect of inoculum size on alkaline Lmethioninase production by $A$. ustus

With the increase in the inoculum size, the enzyme productivity increased, reaching the maximum at $2.0 \mathrm{~mL}$ of spore suspension $(55.21 \pm 2.10 \mathrm{U} / \mathrm{mg}$ protein). With further 
increase in inoculum size, the enzyme productivity decreased (Fig. 5).

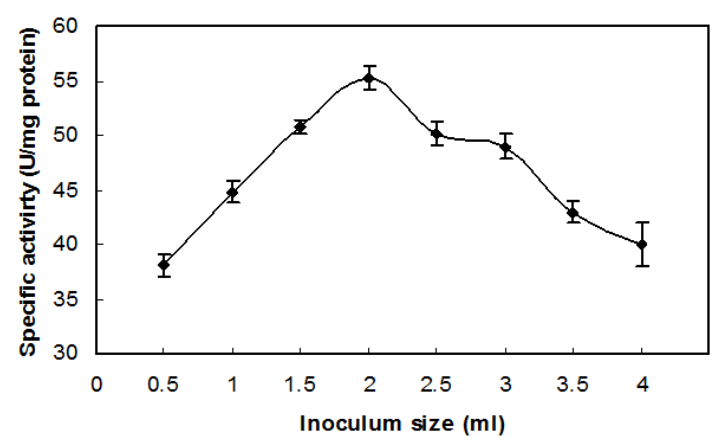

Figure 5- Effect of inoculum size on alkaline Lmethioninase production by A. ustus under SSF.

Effect of initial pH on alkaline Lmethioninase production by $A$. ustus

Figure 6 revealed that the productivity of Lmethioninase increased with increasing the alkalinity of the medium to reach maximum yield at $\mathrm{pH} 8.5(63.2 \pm 1.41 \mathrm{U} / \mathrm{mg}$ protein $)$.

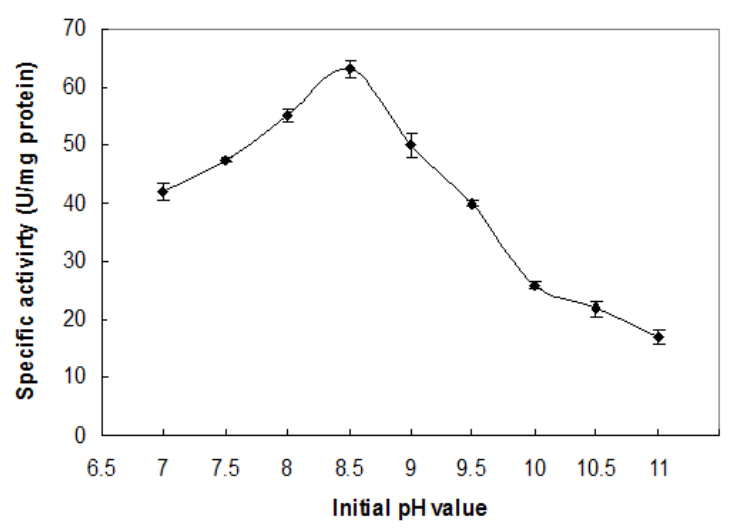

Figure 6- Effect of initial $\mathrm{pH}$ on alkaline Lmethioninase production by A. ustus under SSF.

Effect of different vitamins on alkaline Lmethioninase production by $A$. ustus

As shown in Figure7, the addition of pyridoxine led to an increase in enzyme production compared with control (79.54 \pm $2.05 \mathrm{U} / \mathrm{mg}$ protein).

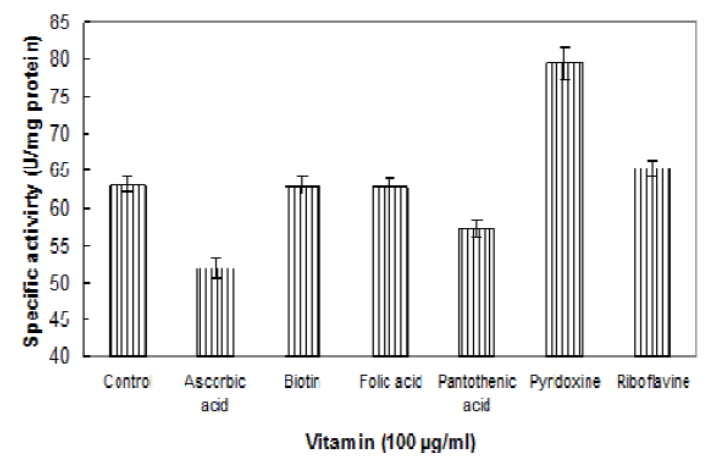

Figure 7- Effect of different vitamins on alkaline L-methioninase production by A. ustus under SSF.

Effect of different additives on alkaline Lmethioninase production by $A$. ustus

As shown in Figure 8, the addition of beet molasses to optimized salt basal medium by $(20 \%, \mathrm{v} / \mathrm{v})$ resulted high increase in Lmethioninase production by A. ustus compared with the control $(99.56 \pm 1.63 \mathrm{U} / \mathrm{mg}$ protein) followed by cane molasses $(85.32 \pm 0.89$ $\mathrm{U} / \mathrm{mg}$ protein ) and corn steep liquor (82.56 $\pm 1.02 \mathrm{U} / \mathrm{mg}$ protein).

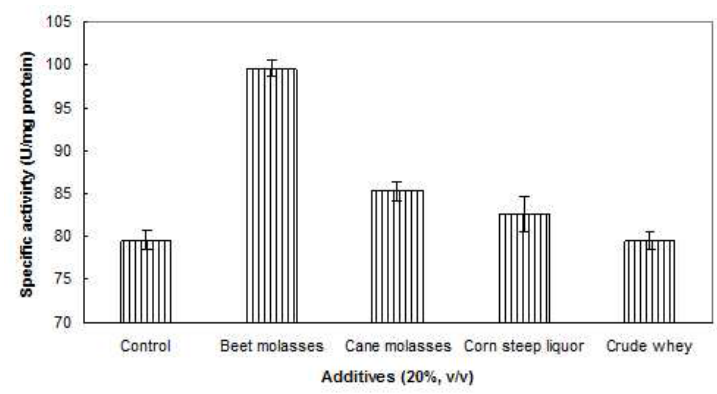

Figure 8- Effect of differentadditives on alkaline L-methioninase production by $A$. ustus under SSF.

\section{DISCUSSION}

The production of L-methioninase under submerged conditions has been reported by Raimbault and Alazard (1980), Khalaf and ElSayed (2009). Many microorganisms including fungi attack methionine but do not grow on it, perhaps because of their inability to methabolize the deaminated $(\alpha$ ketomethionine) and demethiolated ( $\alpha$-ketobutric acid and methaniol) residues of Lmethionine. The inability of filamentous fungi to grow on L-methionine may be partially overcome by the use of a growth-supporting organic compound such as glucose, or an equivalent carbohydrates desinated as a codissimilater (Lockwood and Coombs 1999). From the screening experiment, A. ustus was the most potent fungal isolate for alkaline Lmethioninase production. Therefore, it was selected for further study. These results were in accordance with Ruiz-Herrera and Starkey (1969b) and El-sayed (2009) who recorded the production of L-methioninase by different species of Aspergillus. On the other hand, E. nidulans, E. quadrilineata and $H$. insolens did not show any enzyme activity.

Supplementation of the SmF medium of $A$. ustus with various nitrogen sources showed that none of the incorporated nitrogenous compound had a stimulatory effect on alkaline 
L-methioninase production, except Lmethionine. It could be concluded that the induction of L-methioninase by A. ustus was L-methionine dependent (inducible enzyme) and was not only nitrogen regulated. These results were in accordance with that for Lmethioninase production by Aspergillus sp. (Ruiz-Herrera and Starkey 1969a), Yarrwia lipolytica (Bondar et al. 2005) and A. flavipes (Khalaf and El-Sayed, 2009). However, Lmethioninase production by Pseudomonas putina (Tan et al.1998) and Geotricum candidum (Bonnarme et al. 2001) were Lmethionine independent.

Among different carbon sources, Sucrose exerted the highest increase in the enzyme production as compared with other carbon sources. Similar results obtained for Lmethioninase production by Pseudomonas ovalis (Tanaka et al. 1976) and Trichoderma vaginalis (Lockwood and Coombs 1999). The considerable decrease in the production of the enzyme in the absence of carbon source could be attributed the ability of $A$. ustus to utilize Lmethionine to start the growth but it could not utilize its catabolized products to continue. This result was similar to reported by Khalaf and El-Sayed (2009). In contrast, Ruiz-Herrera and Stakey (1969b) and Khalaf and El-Said (2009) reported that glucose was the favored carbon source for L-methioninase production by filamentous fungi.

Shaking velocity is known as a possible parameter affecting enzyme productivity. This may be attributed to the mechanical forces that can lead to vacuolation of older hyphal compartments, which may lead to weakened hyphae and /or accelerating hyphal fragmentation (Paul et al. 1994).

Physiologically, SSF holds potential for the production of enzymes. This system offers numerous advantages, including high volumetric productivity, relatively higher concentration of the products, less effluent generation and requirement for simple fermentation equipment (Sharma et al. 1991). Moreover, bounded amino acids (solid substrates) are more stable chemically than free ones, therefore, the former are preferred for broad technological application as substrates for bulk production of economically valuable compounds (Delgado-Andrade et al. 2007; El-Sayed et al. 2012).

The variation on the inductivity on the production of alkaline L-methioninase A. ustus according to the type and nature of solid substrate may be closely related to fluctuations in the chemical composition of these compounds (El-Sayed 2009). The preferential use of wheat bran may be attributed to their high protein content $(18 \%)$ and methionine $(1.5 \%)$ relative to their ratios of ash and fiber in comparison to other substrates (Yamazaki et al. 1988). In addition to their unique mechanical properties as structure retention and lack of particle agglomeration (El-Sayed, 2009). Therefore, wheat bran was selected as the optimal solid substance for subsequent cultural optimization to enhance the enzyme productivity by $A$. ustus.

With respect to the effect of initial moisture content, increasing moisture level may cause decreasing in the porosity of substrate, thus limiting the oxygen transfer into the substrate (Raimbault and Alazard 1980). Similar result was obtained by El-Sayed (2009) who recorded a great decrease in L-methioninase productivity obtained from A. flavipes with increasing the moisture content of solid substance.

Inoculum size is also an important factor that influences the production of metabolites under SSF conditions. This may be attributed to nutrient limitation, accumulation of spore selfinhibiting and non-volatile substances (Pandey et al. 1999), or an increase in initial moisture contents causing substrate agglomeration and lower $\mathrm{O}_{2}$ transfer (Hesseeltine 1972).

The importance characteristic of most alkalophilic microorganisms is their strong dependence on the extracellular $\mathrm{pH}$ of the medium, which has a great effect on the cell growth and enzyme production. The present results were in line with that for Lmethioninase production by Clostridium sporogenes at $\mathrm{pH} 8.5$ (Kreis and Hession 1973).

The supplementation of the solid cultures of $A$. ustus for L-methioninase production with different vitamins also investigated. The induction effect of addition pyridoxine is in complete accordance with that recorded for Clostridium sporogenes (Kreis and Hession 1973), followed by riboflavin. Biotin and folic acid showed no stimulatory effect on enzyme production; ascorbic acid and pantothenic acid resulted in significant decrease in the productivity of alkaline L-methioninase. Similar result was obtained by El-Sayed (2009) who recorded a great decrease in L- 
methioninase production by $A$. flavipes by using ascorbic acid.

There were no reports on the influence of different natural additives such as beet and cane molasses, corn steep liquor and whey on alkaline L-methioninase production. The present study found that beet molasses showed a considerable stimulatory effect on enzyme production. Beet molasses is one of the cheapest sources of carbohydrates (12.87\%), nitrogenous substances $(0.227 \%)$ and minerals (\%) $\mathrm{Na} 0.32, \mathrm{~K} 0.66, \mathrm{Ca} 1.00, \mathrm{Mg} 0.37, \mathrm{Fe}$ 1.09, Mn (0.06) and $\mathrm{Zn}(0.248)$. In addition, several vitamins such as thiamine, riboflavin, pyridoxine, folic acid and biotin are present in beet molasses (Crueger and Crueger 2000).

\section{CONCLUSIONS}

A locally isolated fungal strain of A. ustus was used for the production of alkaline Lmethioninase in submerged culture condition. However, better results were obtained in solidstate fermentation using wheat bran as substrate. The yield of L-methioninase in SSF was 5.45-fold higher than SmF.

\section{REFERENCES}

Bergstorm M, Ericson K, Hagenfeldt L. PET study of methionine accumulation in glioma and normal brain tissue: competition with branched chain amino acids. J Comput Assist Tomogr. 1987; 11: 208-213.

Bondar DC, Beckerich JM, Bonnarme P. Involvement of a branched-chain aminotransferase in production of volatile sulfur compounds in Yarrwiali polytica. Appl Environ Microbiol. 2005; 71: 4585-4591.

Bonnarme P, Lapadatescu C, Yvon M, Spinnler HE. L-methionine degradation potentialities of cheese-ripening microorganisms. J Dairy Res. 2001; 68: 663-674.

Cellarier E, Durando X, Vasson MP, Farages MC. Methionine dependency and cancer treatment. Cancer Treat Rev. 2003; 29: 498-499.

Crueger W, Crueger A. Substrates for industrial fermentation. In: Biotechnology, A Text Book of Industrial Microbiology, New Delhi: Panima Publishing Corporation, 2000. pp 5962.

Delgado-Andrade C, Seiquer I, Navarro MP. Millard reaction products consumption: magnesium bioavailability and bone mineralization in rats. Food Chem. 2007; 107: 631-639.

El-Sayed ASA. L-Methioninase production by Aspergillus flavipes under solid state fermentation. J Basic Microbiol. 2009; 49: 331-341.

El-Sayed ASA. L-Methioninase: production, molecular characterization, and therapeutic applications. Appl Microbiol Biotechnol. 2010; 86: 445-467.

El-Sayed ASA, Shindia AA, Zaher Y. L-Amino acid oxidase from filamentous fungi:screening and optimization. Ann Microbiol. 2012; 62:773-784.

Halpern BC, Clark BR, Hardy DN. The effect of replacement of methionine by hemocystine on survival of malignant and normal adult mammalian cells in culture. Proc Natl Acad Sci. 1974; 71: 1133-1136.

Hawkins DS, Park JR, Thomson BG. Asparaginase pharmacokinetics after intensive polyethylene glycol-conjugated L-asparaginase therapy for children with relapsed acute lymphoblastic leukemia. Clin Cancer Res. 2004; 10: 53355341.

Hesseeltine CW. Solid state fermentation. Biotechnol Bioeng. 1972; 14: 517-532.

Horvath RS. Microbial co-metabolism and the degradation of organic compounds in nature. Bacteriol Rev.1972; 36: 146-155.

Khalaf SA, El-Sayed ASA. L-methioninase production by filamentous fungi. I. Screening and optimization submerged condition. Curr Microbiol. 2009; 58: 219-226.

Kokkinakis DM, Schold SC, Hori H, Nobori T. Effect of long-term depletion of plasma methionine on the growth and survival of human brain xenografts in athymic mice. Nutr Cancer. 1997; 29: 195-204.

Kreis W, Hession C. Isolation and purification of L-methionine- $\alpha$-deamino- $\gamma$-mercaptomethane-lyase (L-methioninase) from Clostridium sporogenes. Cancer Res.1973; 33:1862-1865.

Lockwood BC, Coombs GH. Purification and characterization of methionine $\gamma$-lyase from Trichomonas vaginalis. Biochem J. 1999; 279:675-682.

Lowry OH, Rosebrough NJ, Farr AL, Randall RJ. Protein measurements with the Folin phenol reagent. J Biol Chem.1951; 93: 265-275.

Pandy S, Soccol CR, Selvakumar P, Nigam P. Solid state fermentation for production of industrial enzymes Curr Sci.1999; 77: 149162.

Paul GC, Kent Cam, Thomas CR. Hyphal vacuolation and fragmentation in Penicillium chrysogenum. Biotechnol Bioeng. 1994; 44: 655-660.

Raimbault M, Alazard D. Culture method to study fungal growth in solid fermentation. Eur $J$ Appl Microbiol Biotechnol. 1980; 9:199-209.

Ruiz-Herrera J, Starkey RL. Dissimilation of methionine by fungi. J Bacteriol. 1969a; 99:544-551. 
Isaac, GS et al.

Ruiz-Herrera Jand Starkey RL. Dissimilation of methionine by a demethiolase of Aspergillus species. J Bacteriol. 1969b; 99:764-770.

Sharma DK, Niwas S, Behera BK. Solid-state fermentation of bagasse for the production of cellulose enzyme from cellulolytic fungi and extent of simultaneous production of reducing sugars in the fermentation. $J$ Biotechnol. 1991; 6: 7-14.

Tanaka H, Esaki N, Yamamoto T, Sodo K. Purification and properties of methioninase from Pseudomonas ovalis. FEBS Lett.1976; 66:307-311.

Tan Y, Sun X, Xu M. Polyethylene glycol conjugation of recombinant methioninase for cancer therapy. Protein Expr Purif. 1998; 12:45-52.
Tan Y, Xu Mand Tan X. Overexpression and largescale production of recombinant l-methionine$\alpha$-deamine- $\delta$-mercaptomethane-lyase for novel anticancer therapy. Protein Expr Purif. 1997; 9: 233-245.

Thompson JF, Morrison GR. Determination of organic nitrogen: control of variables in the use of Nessler's reagent. Anal Chem.1951; 23:1153-1157.

Yamazaki M, Lopez PL, Kaku K. The bioavailability of nutrient in some Philippine feeds stuffs to poultry. Jpn Agric Res Quart. $1988 ; 22(3)$.

Received:15-Aug-2015

Accepted:12-Out-2015 